\title{
THE COMPARISON OF QUALITATIVE COMPOSITION OF THE MUSCLE TISSUE OF BROWN TROUT, RAINBOW TROUT AND BROOK TROUT
}

\author{
Y. O. Barylo, Y. V. Loboiko \\ y.bachuk.1v@ukr.net
}

Lviv National University of Veterinary Medicine and Biotechnologies named after S. Z. Gzhytsky, 50 Pekarska str., Lviv 79010, Ukraine

Intensification and development potential of the aquaculture sector have created problems relating to the ecological purity and quality of the final fish product. In the conditions of Ukraine, there is extremely little information regarding the objects of trout fishing. Therefore, the purpose of our work was to investigate and analyse individual chemical and biochemical parameters of muscle tissue of commercially profitable and valuable indigenous species of salmon fish grown under the same conditions.

As the materials for research the brown trout (Salmo trutta m. fario), rainbow trout (Oncorhynchus mykiss) and brook trout (Salvelinus fontinalis) in the age of a year and a half (1+) served.

According to the results of the research, moisture composition in the muscular tissue of brown trout was higher compared to rainbow trout and brook trout $(P<0.01)$. In brook and rainbow trout, the amount of the protein is significantly higher $(P<0.01)$ than in brown trout. The content of ash in brook trout, brown and rainbow trout was $1.23 \%, 1.16 \%, 1.25 \%$, respectively. The percentage of total lipids in the muscle tissue of rainbow trout and brook trout was significantly higher than in brown trout $(P<0.01)$. The higher content of free cholesterol and mono- and diacylglycerols in brook trout compared to the brown and rainbow trout $(P<0.01)$ was noticed.

Keywords: TROUT, PROXIMATE COMPOSITION, TOTAL LIPID, LIPID CLASSES, SALMO TRUTTA m. FARIO, ONCORHYNHUS MYKIS, SALVELINUS FONTINALIS

\section{ПОРІВНЯННЯ ЯКІСНОГО СКЛАДУ М'ЯЗОВОЇ ТКАНИНИ СТРУМКОВОЇ ФОРЕЛІ, РАЙДУЖНОЇ ФОРЕЛІ ТА АМЕРИКАНСЬКОЇ ПАЛІЇ}

\author{
Є. О. Барило, Ю. В. Лобойко \\ y.bachuk.1v@ukr.net
}

Львівський національний університет ветеринарної медицини

та біотехнологій імені С. З. Гжицького,

вул. Пекарська, 50, м. Львів, 79010, Україна

Інтенсифікаиія і потениіал розвитку сектора аквакультури створили проблеми, щчо стосуються екологічної чистоти і якості кінцевої рибної продукції. В умовах України надзвичайно мало інформації, яка стосується зокрема об'єктів форелівництва. Тому метою нашої роботи було дослідити і проаналізувати окремі хімічні та біохімічні показники м'язової тканини комерційно прибуткових та цінних аборигенних видів лососевих риб, вирощених в однакових умовах.

Матеріалом для досліджень слугували дволітки (1+) струмкової форелі (Salmo trutta m. fario), райдужної форелі (Oncorhynchus mykiss) та американської палії (Salvelinus fontinalis). Годівля здійснювалася кормами «Aller Aquа». Показники хімічного складу води иього господарства відповідали державному стандарту СОУ 05.01-37-385:006.

За результатами досліджень, вміст вологи у м'язовій тканині струмкової форелі був вищим порівняно з райдужною фореллю та американською палією (гольцем) $(P<0,01)$. У гольия та райдужної форелі значення білка вірогідно вище $(P<0,01)$, ніж у струмкової форелі. Вміст золи в американської палії, струмкової та райдужної форелі становив 1,23\%, 1,16\%, 1,25\% відповідно. Відсоток загальних ліпідів у м'язовій тканині райдужної форелі та американської палії був суттєво вищим порівняно зі струмковою фореллю $(P<0,01)$. Встановлено вищий вміст вільного холестеролу та моно- $i$ диацилгліцеролів у американської палії порівняно зі струмковою і райдужною фореллю $(P<0,01)$.

Результати вказують на те, щьо досліджені види мають високу харчову цінність. Після аналізу складу м'язової тканини досліджуваних риб встановлено, що американська палія характеризувалася дещо вищими якісними показниками, зокрема такими, як вміст сухої речовини, білок та ліпіди. 


\title{
СРАВНЕНИЕ КАЧЕСТВЕННОГО СОСТАВА МЫШЕЧНОЙ ТКАНИ РУЧЬЕВОЙ ФОРЕЛИ, РАДУЖНОЙ ФОРЕЛИ И АМЕРИКАНСКОЙ ПАЛИИ
}

\author{
Е. А. Барило, Ю. В. Лобойко \\ y.bachuk.1v@ukr.net
}

Львовский национальный университет ветеринарной медицины

и биотехнологий имени С. З. Гжицкого,

ул. Пекарская, 50, г. Львов, 79010, Украина

Интенсификация и потенциал развития сектора аквакультуры создали проблемы, касаюшиеся экологической чистоты и качества конечной рыбной продукции. В условиях Украины чрезвычайно мало информации, касающейся, в частности, объектов форелеводства. Поэтому изелью нашей работь было исследовать и проанализировать отдельные химические и биохимические показатели мьпиечной ткани коммерчески прибыльных и ценных аборигенных видов лососевых рыб, выращенных в одинаковьх условиях.

Материалом для исследований послужили двухлетки (1+) ручьевой форели (Salmo trutta m. fario), радужной форели (Oncorhynchus mykiss) и американской палии (Salvelinus fontinalis). Кормление осуществлялась кормами «Aller Аqиа». Показатели химического состава воды данного хозяйства отвечали государственному стандарту СОУ 05.01-37-385:006.

По результатам исследований содержание влаги в мымечной ткани ручьевой форели было выше по сравнению с радужной форелью и американской палией (гольцом) $(P<0,01)$. В гольиа и радужной форели значение белка достоверно выше $(P<0,01)$, чем в ручьевой форели. Содержание золь в американской палии, ручьевой и радужной форели составило 1,23\%, 1,16\%, 1,25\% соответственно. Процент общих липидов в мышечной ткани радужной форели и американской палии был существенно выле по сравнению с ручьевой форелью $(P<0,01)$. Установлено высокое содержание свободного холестерина и монои диацилглицеролов в американской палии по сравнению с ручьевой и радужной форелью $(P<0,01)$.

Результаты исследований указывают на то, что данные виды имеют высокую пищевую изенность. После анализа состава мышечной ткани исследуемых рыб установлено, что американская палия характеризовалась несколько более высокими качественными показателями, в частности такими, как содержание сухого вещества, белок и липиды.

Ключевые слова: ФОРЕЛЬ, БЕЛОК, ЗОЛА, ВЛАГА, ОБЩИЕ ЛИПИДЫ, КЛАССЫ ЛИПИДOВ, SALMO TRUTTA m. FARIO, ONCORHYNHUS MYKIS, SALVELINUS FONTINALIS

In Ukrainian coldwater fish-breeding enterprises the most farmed salmon species are rainbow trout Oncorhynhus mykis W., brook trout Salvelinus fontinalis and the demand for growing local species - brown trout Salmo trutta morfa fario L. is increasing [15].

In the waters of the Ukrainian Carpathians brown trout (Salmo trutta morpha fario L., 1758) is still a native species [27]. This type of trout is one of the most attractive species, in particular because of the taste, dietary properties and demand among fishermen [20].

Brook trout (char) is mainly grown as an amateur and sport fishing object [28]. However, an increase in the volumes of cultivation and marketing of brook trout can increase the diver- sity of salmon products [31]. The cultivation of this fish may represent a potentially new sector for the aquaculture market [13].

The availability of data on the qualitative composition of some salmon fish flesh contributes to a deeper scientific understanding of the issue of diet-related nutrition [39].

According to the literature sources chemical composition of trout flesh, in addition to genetic factors, also depends on the quality of water, feeding, season, age and size of fish [32].

Trout flesh is a source of polyunsaturated fatty acids, such as n-3 and n-6 and is low in cholesterol amount [12]. Therefore, it is an important component of a balanced diet for people [38]. Fish is considered a source of animal protein, and plays 
a special role in improving the physical and intellectual development of humans due to its good nutritional value [35].

Proteins have numerous structural and metabolic functions. The deposition of protein is one of the main determinants of live weight (biomass) in fish [9].

Lipids belong to one of the most informative biochemical characteristics of fish, because these components play an important role as a source of metabolic energy, including restoration and adaptive mechanisms and perform structural functions in cell membranes [40]. Lipids are usually considered as a component of fish muscle, which is used to evaluate the quality of fish meat [22] because they contain essential fatty acids [30]. The nature and the quantity of fish lipids depend on species and habitats [34].

The detailed analysis of the basic information on individual quality indicators of trout meat for assessing the nutritional composition is very necessary for both fish suppliers and consumers [10].

Information on fish chemical composition is highly relevant for the standardization of food products based on nutritional criteria. Lack of information on trout products, highly appreciated on the market, triggers interest in current research aiming at the analysis of body weight, chemical composition of fish flesh and other technological and qualitative parameters [37]. According to Jabeen [17], the information on the nutrients content will facilitate the classification of fish in qualitative composition and will help to determine the market price of fish and consumer health benefits.

Therefore, the purpose of the research is to determine the individual chemical and biochemical parameters of muscle tissue of salmon fish grown under the same conditions.

\section{Materials and methods}

The study was performed on three kinds of salmon at the age of year and a half $(1+)$. They were brown trout (Salmo trutta morfa fario Linnaeus, 1758), rainbow trout (Oncorhynchus mykiss Walbaum, 1792) and brook trout (Salvelinus fontinalis Mitchill, 1814) weighing $132.07 \pm 0.239 \mathrm{~g}$, $262.12 \pm 2.459 \mathrm{~g}$ and $288.56 \pm 3.640 \mathrm{~g}$, respectively. All three species of fish were grown in the con- crete basins of the farm, which is located in the Transcarpathian region (Ukraine) at an altitude of $450 \mathrm{~m}$ above the sea level. Water supply came from a mountain river. Feeding was done by Aller Aqua feeds.

In this work we weighed fish (g), determined the content of protein, moisture, dry matter, ash, as well as the content of total lipids and their classes in raw muscle tissue from the dorsal part of the body.

Proximate composition. The samples of fish muscle were dried for 24 hours at $100-105^{\circ} \mathrm{C}$ according to the AOAC [3]. Ash content was determined by burning sample for $12 \mathrm{~h}$ in a furnace at $550{ }^{\circ} \mathrm{C}$ [2]. Results were expressed as percentage to the wet weight.

Total protein concentration was estimated by the method of Lowry et al. [25], which is the most sensitive and can detect its content at the level of $5 \mu \mathrm{g} / \mathrm{ml}$ [18]. This method is based on the reaction of $\mathrm{Cu}^{+}$, produced by peptide bond oxidation, with Folin reagent.

Total lipids in muscles were investigated to the method of Folch et al. [14]. According to this method, samples were extracted using chloroform/methanol $(2: 1, \mathrm{v} / \mathrm{v})$ and were separated into classes using thin layer chromatography with silicagel (TLC). These analyses were performed in five approaches $(\mathrm{n}=5)$.

Statistical processing of the results of the research was conducted using the software ANOVA. Differences were considered to significant at $\mathrm{P}<0.05$ and $\mathrm{P}<0.01$. The results of the analyses were presented as means of standard deviation $( \pm \mathrm{SD})$.

\section{Results and discussion}

The comparative analysis of the chemical composition of muscle tissue of the body of three species of trout grown under the same conditions is given in table 1.

The high moisture content increases the fishes' susceptibility to microbial spoilage, oxidative degradation of polyunsaturated fatty acids and consequently decreases the quality of the fishes for longer preservation time [29].

The highest moisture content of the studied fish species was in brown trout and was $76.97 \%$, which is significantly higher than rainbow trout and 
brook trout $(\mathrm{P}<0.01)$. Accordingly, the dry matter content was higher $(\mathrm{P}<0.01)$ in $O$. mykiss and $S$. fontinalis relative to $S$. trutta $f$. The corresponding literature data indicate that the moisture content was $77.43 \%$ of the brown trout filet [21], $73.7 \%$ in rainbow trout [37] and $76.94 \%$ in brook trout [7].

Compared to rainbow trout, brook trout had slightly higher protein content, but no significant difference was found, however, the protein in these species was significantly higher $(\mathrm{P}<0.01)$ than in brown trout.

The average content of ash in brook trout was $1.23 \%$ and $1.16 \%, 1.25 \%$ in brown and rainbow trout $(\mathrm{P}<0.05)$. These results are similar to those reported by for brown trout [21] and brook trout [19].

According to Rasmussen \& Ostenfeld (2000), the average amount of ash in fish ranged from 0.8 to $1.4 \%$, but may exceed this percentage due to the number of intramuscle fish bones in the fillet. According to literary data, the muscle tissue of brook trout contains significantly higher protein, lipid, and dry matter compared to rainbow trout. Also, according to Tidballb et al. (2017), wild brook trout has higher protein content than domesticated and wild rainbow trout.

For physiological reasons, there is a very close relationship between moisture and protein content in fish flesh. This metric also varies with age and size [5].

The content of total lipids (table 2) in the muscle tissue of rainbow trout and brook trout was significantly higher than in rainbow trout $(\mathrm{P}<0.01)$ and was $4.78 \%$ and $5.65 \%$.

According to the content of lipids, fishes are classified into lean fish ( $<2 \%$ fat), low fat fish
Proximate composition muscle tissue of three trout species (Salmo trutta fario L., Oncorhynchus mykiss, Salvelinus fontinalis)

\begin{tabular}{|l|c|c|c|}
\hline Parameters & Brown trout & Rainbow trout & Brook trout \\
\hline Moisture, \% & $76.97 \pm 0.044$ & $76.43 \pm 0.150^{\text {aa }}$ & $75.72 \pm 0.349^{\text {aa }}$ \\
\hline Dry matter, \% & $23.03 \pm 0.044$ & $23.57 \pm 0.150^{\text {aa }}$ & $24.28 \pm 0.349^{\text {aa }}$ \\
\hline Protein, $\mathrm{mg} / \mathrm{g}$ & $19.00 \pm 0.304$ & $24.45 \pm 0.295^{\text {aa }}$ & $25.33 \pm 0.521^{\text {aa }}$ \\
\hline Ash, \% & $1.16 \pm 0.025$ & $1.25 \pm 0.027^{\text {a }}$ & $1.23 \pm 0.035$ \\
\hline
\end{tabular}

Note: ${ }^{\mathrm{a}}-\mathrm{P}<0.05$, aa $-\mathrm{P}<0.01$ for brown trout / rainbow trout, brown trout / brook trout; ${ }^{\mathrm{b}}-\mathrm{P}<0.05,{ }^{\mathrm{bb}}-$ $\mathrm{P}<0.01$ for rainbow trout / brook trout.

(2-4\% fat), medium fat fish ( $4-8 \%$ fat) and high fat fish ( $>8 \%$ fat) [1]. Based on the above-mentioned classification, rainbow trout and brook trout are fishes with an average fat content, and brown trout belongs to the category of fish with low fat content.

This difference in the content of total lipids in the muscle tissue of rainbow trout, brook and brown trout can be partly explained by genetic features. Also, according to Souza et al. [37] in fish with a larger body weight the fat deposition is more intense. It is also confirmed by the fact that fish with a lower percentage of moisture has more lipids and protein [8].

According to Kaya, the content of total lipids in cultivated $S$. truttaf., on average was $3.62 \%$, for wild one it was $2.7 \%$ [42]. In rainbow trout the content of total lipids was 3.10-4.68 \% [10]. Also according to Souza (2015) in the rainbow trout fillet the given figure was $6.5 \%, 4.3 \%$ [42].

It was found that the dominant classes among lipids in all three fishes studied were triacylglycerols and slightly less phospholipids. Similar data indicates [33] for Arctic charr (Salvelinus alpinus L.), although Keriko et al. (2010) reports

The ratio of total lipids and there classes in muscle tissue of three trout species

Table 2 (Salmo trutta fario L., Oncorhynchus mykiss, Salvelinus fontinalis)

\begin{tabular}{|l|c|c|c|}
\hline \multicolumn{1}{|c|}{ Parameters } & Brown trout & Rainbow trout & Brook trout \\
\hline Total lipid (\%) & $2.42 \pm 0.270$ & $4.78 \pm 0.310^{\text {aa }}$ & $5.65 \pm 0,247^{\text {aa }}$ \\
\hline $\begin{array}{c}\text { Lipid class (\%) } \\
\text { phospholipid }\end{array}$ & $27.50 \pm 0.172$ & $22.88 \pm 0.501^{\text {aa }}$ & $20.53 \pm 0.158^{\text {aa,bb }}$ \\
\hline free cholesterol & $9.30 \pm 0.090$ & $10.45 \pm 0.125^{\text {aa }}$ & $13.78 \pm 0.280^{\text {aa,bb }}$ \\
\hline mono- and diacylglycerols & $4.46 \pm 0.454$ & $9.51 \pm 0.099^{\text {aa }}$ & $13.15 \pm 0.277^{\text {aa,bb }}$ \\
\hline non-esterified fatty acids (NEFA) & $10.60 \pm 0.148$ & $11.65 \pm 0.188^{\text {aa }}$ & $10.49 \pm 0.208^{\text {bb }}$ \\
\hline triacylglycerol & $27.88 \pm 0.229$ & $33.40 \pm 0.695^{\text {aa }}$ & $28.47 \pm 0.287^{\text {bb }}$ \\
\hline cholesterol ester & $20.27 \pm 0.591$ & $12.13 \pm 0.187^{\text {aa }}$ & $13.58 \pm 0.191^{\text {aa,bb }}$ \\
\hline
\end{tabular}

Note: ${ }^{\text {aa }}-\mathrm{P}<0.01$ for brown trout / rainbow trout, brown trout / brook trout; ${ }^{\text {bb }}-\mathrm{P}<0.01$ for rainbow trout / brook trout. 
that in the muscular tissue of the fish species studied, such as common carp (Cyprinus carpio), mirror carp (Cyprinus specularis), largemouth bass (Micropterus salmoids) and tilapia (Oreochromis leucosticus), phospholipids were the highest.

The content of phospholipids and cholesterol esters in the muscle tissue of rainbow trout was 27.50 and $20.27 \%$, which was significantly higher $(\mathrm{P}<0.01)$ relatively to other fish species studied. There is also a significant difference between the data of the classes of lipids between rainbow trout and brook trout $(\mathrm{P}<0.01)$.

The phospholipids are all contained in membrane structures, including the outer cell membrane, the endoplasmic reticulum and other intracellular tubule systems, as well as membranes of the organelles like mitochondria. In addition to phospholipids, the membranes also contain cholesterol, contributing to the membrane rigidity [16].

According to Moriya, phospholipids consist mainly of polyunsaturated fatty acids (PUFAs), which are extremely useful for human nutrition [11]. Some of the phospholipids classes have been reported to possess antioxidant properties [23].

The content of free cholesterol mono- and diacylglycerols had a significant difference $(\mathrm{P}<0.01)$ between $O$. mykiss and $S$. fontinalis and was higher relative to $S$. trutta $f$. $(\mathrm{P}<0.01)$. In rainbow trout the content of non-esterified fatty acids (NEFA) and triacylglycerol was significantly higher compared to brown trout $(\mathrm{P}<0.01)$ and brook trout $(\mathrm{P}<0.01)$. The triglycerides are lipids used for storage of energy in fat depots, usually within special fat cells [16], and they act as depot for storing nutrients in the body of fish $[36,4]$ and are used as the main indicator of the biochemical condition of fish [41]. The triglycerides reflect the fatty acid composition of the food to a greater extent than phospholipids do [6].

According to Lochmann, mono- and diacylglycerols, cholesterol esters are important forms of long-term energy stores.

Thus, the research results show that the muscle tissue of all selected fishes is a good source of protein, minerals and lipids.

\section{Conclusion}

The obtained results of chemical and biochemical studies of muscle tissue of three species of salmon (Salmo trutta morfa fario L., Oncorhynhus mykis W., Salvelinus fontinalis M.) indicate that these species have high nutritional value. After analyzing the muscle composition of the investigated fish, it was established that the brook trout was characterized by somewhat higher qualitative parameters, in particular, such as dry matter, protein and lipids.

Prospects for further research. For a more detailed analysis of the quality of muscle tissue, it is advisable to investigate its fatty acid composition in brown trout, rainbow trout and brook trout.

1. Ackman R. G. Seafood lipids. In: Shahidi F., Botta J. R. (Eds.). Seafoods, Chemistry, Processing Technology and Quality. Blackie Academic \& Profesional, Glasgow London, 1994, pp. 34-48. DOI: 10.1007/978-1-4615-2181-5 4.

2. AOAC (Association of Official Analytical Chemists). Official methods of analysis of the Association of Official Analytical Chemists. $13^{\text {th }}$ ed. Washington, D.C., 1980.

3. AOAC. Official Methods of Analysis of the Association of Official Analytical Chemists. $16^{\text {th }}$ ed. Arlington, V.A, Author. 1995. DOI: 10.3923/jfas.2013.295.298.

4. Barylo Ye. Biochemical and morphometric parameters of pre-larvae of three salmonids species at one-day age. Fisheries science of Ukraine, 2016, 2 (36), pp. 38-47. (in Ukrainian)

5. Breck J. E. Body composition in fishes: body size matters. Aquaculture, 2014, 433 (20), pp. 40-49. DOI: 10.1016/j.aquaculture.2014.05.049.

6. Cakmak O., Altuntas A., Ugurcu V., Erdemli H. K., Akyol S. Female Leuciscus lepidus May Be a New Alternative for Fish Oil Supplements. Journal of Chemistry, 2015, 7 p. DOI: 10.1155/2015/696303.

7. Celikkale M. S., Kurtoğlu İ. Z., Sahin S., Sivri N., Akyol A. Gökkusağı (Oncorhynchus mykiss) ve Kaynak Alabalığ (Salvelinus fontinalis)'nın Et Verim Özellikleri ve Etin Biyokimyasal Bileşiminin Karşılaştırılması. III. Su Ürünleri Sempozyumu, Erzurum, 1998, pp. 41-49. (in Turkish)

8. Dempson J. B., Schwar C. J., Shears M., Furey G. Comparative proximate body composition of Atlantic salmon with emphasis on parr from fluvial and lacustrine habitats. Journal of Fish Biology, 2004, 64, pp. 12571271. DOI: $10.1111 /$ j.0022-1112.2004.00389.x.

9. Dumas A., de Lange C. F. M., France J., Bureau D. P. Quantitative description of body composition and rates of nutrient deposition in rainbow trout $(\mathrm{On}$ corhynchus mykiss). Aquaculture, 2007, 263, pp. 165181. DOI: 10.1016/j.aquaculture.2007.09.026.

10. Ehsania A., Mohammad S. J., Khodayaria M. Differentiation of common marketable-size rainbow trouts (Oncorhynchus mykiss) based on nutritional and dietetic traits: a comparative study. Journal of 
Applied Animal Research, 2013, 41 (4), pp. 387-391. DOI: 10.1080/09712119.2013.783483.

11. Exler J., Weihrauch J. L. Comprehensive evaluation of fatty acids in foods. VIII. Finfish. Journal of the American Dietetic Association, 1976, 69 (3), pp. 243-248.

12. Fallah A. A., Saei-Dehkordi S. S., Nematollah A. Comparative assessment of proximate composition, physicochemical parameters, fatty acid profile and mineral content in farmed and wild rainbow trout (Oncorhynchus mykiss). International Journal of Food Science \& Technology, 2011, 46 (4), pp. 767-773. DOI: 10.1111/j.1365-2621.2011.02554.x.

13. Fischer G. J., Held J., Hartleb C., Malison J. Evaluation of brook trout production in a coldwater recycle aquaculture system. Aquacultural engineering, 2009, 41, pp. 109-113. DOI: 10.1016/j.aquaeng.2009.06.012.

14. Folch J., Lees M., Sloane-Stanley G. H. A simple method for the isolation and purification of total lipids from animal tissues. The Journal of Biological Chemistry, 1957, 226, pp. 497-509.

15. Haloyan L., Mruk A., Kucheruk A., Terteryan L. Productive characteristics of age-3 brood brown trout (Salmo trutta) reared in the conditions industrial aquaculture. Fisheries science of Ukraine, 2017, 1 (39), pp. 64-72. DOI: 10.15407/fsu2017.01.064.

16. Huss H. H. Quality and quality changes in fresh fish, FAO Fisheries Technical Paper no. 348, Rome, Italy, 1995.

17. Jabeen F., Chaudhry A. S. Nutritional composition of seven commercially important freshwater fish species and the use of cluster analysis as a tool for their classification. The Journal of Animal \& Plant Sciences, 2016, 26 (1), pp. 282-290.

18. Jan U., Shah M., Manzoor T., Ganie S. A. Variations of Protein Content in the Muscle of Fish Schizothorax niger. American-Eurasian Journal of Scientific Research, 2012, 7 (1), pp. 01-04. DOI: 10.5829/ idosi.aejsr.2012.7.1.64126.

19. Karabulut H. A., Balta F., Yandi İ., Serezli R. The Efects of Diferent Levels of Ascorbic Acid on Growth Performance and Meat Composition of Brook Trout (Salvelinus fontinalis). Kafkas Üniversitesi Veteriner Fakültesi Dergisi, 2011, 17 (2), pp. 303-308. DOI: 10.9775/kvfd.2010.3538.

20. Kaya Y., Erdem M. E. Seasonal comparison of wild and farmed brown trout (Salmo trutta forma fario L., 1758): crude lipid, gonadosomatic index and fatty acids. International Journal of Food Sciences and Nutrition, 2009, 60 (5), pp. 413-423. DOI: $10.1080 / 09637480701777886$.

21. Kaya Y., Erdem M. E., Turan H. Monthly Differentiation in Meat Yield, Chemical and Amino Acid Composition of Wild and Cultured Brown Trout (Salmo Trutta Forma Fario Linneaus, 1758). Turkish Journal of Fisheries and Aquatic Sciences, 2014, 14, pp. 479486. DOI: 10.4194/1303-2712-v14_2_19.

22. Keriko J., Chege M., Magu C. W., Mwachiro M. M., Murigi E. C., Githua A. N. Kareru P. G. Fish lipid contents and classes of selected fish species found in Lake Naivasha (Kenya) and the fish feeding habits of the lake's inhabitants. African journal of pharmacy and pharmacology, 2010, 4 (10), pp. 745-753.

23. King M., Boyd L., Sheldon B. Antioxidant Properties of Individual Phospholipids in a Salmon Oil Model System. Journal of the American Oil Chemists Society, 1992, 69 (6), pp. 545-551. DOI: 10.1007/ BF02636106.

24. Lochmann S. E., Maillet G. L., Frank K. T., Taggart C. T. Lipid class composition as a measure of nutritional condition in individual larval Atlantic cod (Gadus morhua). Canadian Journal of Fisheries and Aquatic Sciences, 1995, 52, pp. 1294-1306. DOI: $10.1139 / \mathrm{f} 95-126$.

25. Lowry O. H., Roserrough N. J., Farr A. L., Randall R. J. Protein measurement with the folin phenol reagent. Journal of Biology and Chemistry, 1951, 193, pp. 265-275.

26. Moriya H., Hosokawa M., Miyashita K. Combination effect of herring roe lipids and proteins on plasma lipids and abdominal fat weight of mouse. Journal of Food Science, 2007, 72 (5), pp. 231-234. DOI: 10.1111/j.1750-3841.2007.00356.x.

27. Mruk A., Terteryan L., Khandozhivska A., Terteryan L. Monitoring of brown trout growth in industrial conditions of the fish farm "Ishkhan". Fisheries science of Ukraine, 2013, pp. 31-37. (in Ukrainian)

28. Okumus I., Bascinar N. A comparative study on water column and bottom feeding habit of tank reared brook trout. Turkish Journal of Marine Sciences, 2002, 8 (1), pp. 17-26.

29. Oluwaniyi O.O., Dosumu O.O. Preliminary studies on the effect of processing methods on the quality of three commonly consumed marine fishes in Nigeria. Biochemistry, 2009, 21 (1), pp. 1-7.

30. Puwastien P., Judprasong K., Kettwan E., Vasanachitt K., Nakngamanong Y. Bhattacharjee L. Proximate Composition of Raw and Cooked Thai Freshwater and Marine Fish. Journal of Food Composition and Analysis, 1999, 12 (1), pp. 9-16. DOI: 10.1006/ jfca.1998.0800.

31. Rasmussen R. S., Ostenfeld T. H. Effect of growth rate on quality traits and feed utilisation of rainbow trout (Oncorhynchus mykiss) and brook trout (Salvelinus fontinalis). Aquaculture, 2000, 184 (3), pp. 327337. DOI: 10.1016/S0044-8486(99)00324-5.

32. Rasoarahona J. R. E., Barnathan G., Bianchini J. P., Gaydou E. M. Influence of season on the lipid content and fatty acid profiles of three tilapia species (Oreochromis nilolicus, O. macrochir and Tilapia rendalli) from Madagascar. Food Chemistry, 2005, 91 (4), pp. 683-694. DOI: 10.1016/j.foodchem.2004.07.001.

33. Ringø E., Vennø A. T., Cato B. I. Effects of starvation on the lipid composition in muscle tissue and liver of hatchery-reared Arctic charr, Salvelinus alpinus (L), from Lake Takvatn. Fiskeridirektoratets Skrifter. Serie Ernoering, 1990, 3, pp. 13-20. 
34. Shamsudin S., Salimon J. Physicochemical characteristics of aji-aji fish (Seriola nigrofasciata) lipids. The Malaysian Journal of Analytical Sciences, 2006, 10 (1), pp. 55-58.

35. Shi P. S, Wang Q., Zhu Y. T., Gu Q. H., Xiong B. X. Comparative study on muscle nutritional composition of juvenile bighead carp (Aristichthys nobilis) and paddlefish (Polyodon spathula) fed live feed. Turkish Journal of Zoology, 2013, 37 (3), pp. 321-328.

36. Shirai N., Suzuki H., Tokairin S., Ehara H., Wada S. Dietary and seasonal effects on the dorsal meat lipid composition of Japanese (Silurus asotus) and Thai catfish (Clarias macrocephalus and hybrid Clarias macrocephalus and Clarias galipinus). Comparative Biochemistry and Physiology. Part A, Molecular \& Integrative Physiology, 2002, 132 (3), pp. 609-619. DOI: 10.1016/S1095-6433(02)00081-8.

37. Souza M. L. R., Macedo-Viegas E. M., Zuanon J. A. S., Carvalho M. R. B., Goes E. S. R. Processing yield and chemical composition of rainbow trout (Oncorhynchus mykiss) with regard to body weight. Acta Scientiarum. Animal Sciences, 2015, 37 (2), pp. 103 108. DOI: $10.4025 /$ actascianimsci.v37i2.24165.

38. Stancheva M., Dobreva D., Merdzhanova A., Galunska B. Vitamin content and fatty acids composi- tion of rainbow trout (Oncorhynchus mykiss). Plodiv. University, Paisii Hilendarski, Bulgaria Scientific Papers, 2010, 37 (5), pp. 117-123.

39. Tidballb M. M., Exlerc J., Somanchic M., Williamsc J., Krafta C., Curtisa P., Tidballa, K. G. Addressing information gaps in wild-caught foods in the US: Brook trout nutritional analysis for inclusion into the USDA national nutrient database for standard reference. Journal of Food Composition and Analysis, 2017, 60, pp. 57-63. DOI: 10.1016/j. jfca.2017.03.004.

40. Tocher D. R. Metabolism and functions of lipids and fatty acids in teleost fish. Reviews in Fisheries Science, 2003, 11 (2), pp. 107-184. DOI: 10.1080/713610925.

41. Weinstein M. P., Litvin S. Y., Guida V. A. Stable Isotope and Biochemical Composition of White Perch in a Phragmites Dominated Salt Marsh and Adjacent Waters. Wetlands, 2010, 30 (6), 1181-1191. DOI: $10.1007 / \mathrm{s} 13157-010-0102-2$.

42. Yeşilayer N., Genç N. Comparison of proximate and fatty acid compositions of wild brown trout and farmed rainbow trout. South African Journal of Animal Science, 2013, 43 (1), pp. 89-97. DOI: 10.4314/ sajas.v43i1.11. 